\title{
放電用岸素電極に関する研究
}

III - 避雷器用炭素電極の試作とその放電特性

\author{
本田英昌*・真田雄三*・古田 毅*・東阪健治 ${ }^{* *}$
}

\section{Carbon Electrode in Electric Spark Discharge}

\section{III - Electric Discharging Test for A Trial Product of Arrester Carbon}

\author{
H. Honda, Y. Sanada, T. Furuta \\ (Resources Research Institute, Kawaguchi-Saitama)
}

and

K. Higashizaka

(Electrical Communication Laboratory, Mitaka-Musashino)

Coal carbon electrodes heat treated at temperatures between $1000^{\circ} \mathrm{C}$ and $2800^{\circ} \mathrm{C}$ were tested with repetitive electric discharge and pulsed electric discharge. The electrode specimens were prepared from the mixture of Akabira weakly-caking coal and the additional matter (natural graphite and pitch) by means of cold molding of $2000 \mathrm{~kg} / \mathrm{cm}^{2}$. The stability of repetitive discharge is the better at heat treatment temperature (HTT) of about $1400^{\circ} \mathrm{C}$ and about $2800^{\circ} \mathrm{C}$, and the one of pulsed discharge is the best at HTT of about $2800^{\circ} \mathrm{C}$. The durability of electrodes increased for the repetitive discharge and decreased for the pulsed discharge with the increase of additional matter. The durability of electrodes for the pulsed discharge showed a maximum at about $15 \%$ of additional matter. The coal carbon electrodes, which contain about $10-30 \%$ additional matter, heat treated at HTT of about $2800^{\circ} \mathrm{C}$ had much better electric discharging properties than the commercial arrester carbons.

\section{1. 緒言}

電話器, 電話局および中継所, ケーブルなどの通信施 設の保安器の一部として放電電極が取付けられている。 雷や外部から誘導され発生した高電圧から上記施設を安 全に保護するため, 放電により接地させるのが通例で, その放電電極として炭素電極が用いられている。これは 炭素電極の動作特性が秀れ, その上, 安価であるからで ある。しかし従来から炭素電極が経験的に用いられてい るのみであって, 従来の避雷器用炭素は上記の目的に必 ずしも満足を与えず，またこの方面の研究は皆無に等い。 放電現象は複雑な現象の一つであって現在でも完全に 理解されていない。絽返し放電, 連続放電, 衝撃放電に

* 資源技術試験所

** 電気通信研究所
対する炭素電極の安定性を炭素自身の有する物理的性質 と直接結びつけることは, なかなか困難である。しかし 炭素電極の気中放電における安定性は, 主として炭素の 電気抵抗, 機械的強度, 屈曲性, 耐熱衝撃性などに依存 することが明らかにされてきた。, ${ }^{1,2}$ また, 炭素電極の液 中放電における安定性も同じく炭素の見掛比重, 機䑾的 強度, 屈曲性, 電気抵抗などに依存することが明らかに された。, ${ }^{3)}$ このほか炭素の仕事函数や種々の電子的性質 が放電特性と密接に関係すると思われる。いずれにして も放電を高密度電流による超高温および㣫撃圧の発生と して理解するならば，極として具備しなければならない 性質は電気伝導度の大きいこと, 機械的強度の大きいこ と, 熱衝撃に強いことなどに要約されるものと思われる。 石炭類炭素材は機械的強度および熱㣫撃は極めて強いが, 電気伝導性が低いことが従来の研究より明らかにされて 
いる $\left.\left.\left.{ }^{6}\right), 7\right), 8\right)$ 従って比較的苛酷な要求をされる避雷器用炭 素材として, 石炭類炭素材を基材とし，これに電気伝導 性の極めて大きい天然黒鉛を添加することにより, 安定 な放電用炭素極となし得ることが考えられる。ここでは このような考えの下に石炭を主体とする炭素電極を試作 し，その放電特性を測定した結果について報告する。

\section{2. 実験方法}

2.1 試 料

原料石炭としてはTable 1 に示す分析值を有する赤 平炭を用いた。

Table 1 Proximate and ultimate analysis of Akabira weakly-caking coal

\begin{tabular}{|c|c|c|c|c|c|c|}
\hline \multicolumn{3}{|c|}{ Proximate analysis } & \multicolumn{3}{c|}{ Ul timate analy si s } \\
\hline $\begin{array}{c}\text { Mois- } \\
\text { ture }\end{array}$ & Ash & Volatile & Fixed & $\mathrm{C}$ & $\mathrm{H}$ & $\mathrm{O}_{+\mathrm{N}+\mathrm{S}}$ \\
$\%$ & $\%$ & matter & \multicolumn{2}{c|}{ carbon d.a.f. } & d. a.f. & d. a f. \\
$\%$ & $\%$ & $\%$ & $\%$ & $\%$ \\
\hline 2.6 & 2.9 & 42.3 & 52.2 & 83.1 & 6.1 & 10.8 \\
\hline
\end{tabular}

試料原炭は Tyler 200 mesh篩下に微粉砕した。以

下試料石炭をA と表わす。

添加材としては精製天然埋鉛 CB \# 400 (325mesh以 下，灰分 $0.5 \%$ 以下)に中ピッチまたは硬ピッチを重量 比でそれぞれ $7: 3$ または $6: 4$ の割に混合し, 100〜150 ${ }^{\circ} \mathrm{C}$ の温度で, ダブルローラー型捏和器により数回混和し, これを更に乳鉢で粗粉研したものを用意した。以下添加 材をNGP と表わす。

試料石炭に対し, 添加材を所定量だけ科量混合し, ボ ールミルにより $5 \sim 6$ 時間混合粉砕し, 添加材が石炭に 出来るだけ均一に分散するようにしたものを実験試料粉 末とした。以下試料石炭 $80 \%$ と添加材 $20 \%$ とを混合し た実験試料をA-NGP 20 , 試料石炭 $60 \%$ と添加材 40 \%とを混合した実験試料をA-NGP 40 の如く表記する。

試料粉末の所要重量を $33 \mathrm{~mm} \times 13 \mathrm{~mm}$ または 130

$\mathrm{mm} \times 50 \mathrm{~mm}$ の型に入れ, $2000 \mathrm{~kg} / \mathrm{cm}^{2}$ の成形Eで室 温成形したものを，鉄製の箱中に入れ，コークス粉をつ め，蓋をして酸化を防ぎながらエレマ炉で焼成した。焼 成条件は室温から $280^{\circ} \mathrm{C}$ まで $60 \sim 120^{\circ} \mathrm{C} / \mathrm{hr}, 280^{\circ} \mathrm{C}$ ら $600^{\circ} \mathrm{C}$ まで $520^{\circ} \mathrm{C} / \mathrm{hr}, 600^{\circ} \mathrm{C}$ から $1000^{\circ} \mathrm{C}$ ま $60 \sim$ $120^{\circ} \mathrm{C} / \mathrm{hr}$ の加熱速度で加熱し, $1000^{\circ} \mathrm{C}$ に 30 分間保持 した。この様にして焼成した素材は避雷器用放電試験装 置に適合するように所定の大きさに加工した後, 蓋付黒 鉛るつぼに入れ，真空式タンマン炉を用い，窒素気流を 流しながら昇温速度約 $20^{\circ} \mathrm{C} / \mathrm{min}$ で $1000^{\circ} \mathrm{C}$ から $2800^{\circ} \mathrm{C}$ の温度範讲で熱処理を行ない, 所要温度に約 30 分保持 した。以下，加熱処理温度をHTT で表わす。このよう
にして得た成形体試料を $26.7 \mathrm{~mm} \times 6.2 \mathrm{~mm} \times 5 \mathrm{~mm}$ の避 雷器用炭素電極として加工仕上げしたものを測定用試料 とした。また焼成試料素材を, ほぼ $100^{\circ} \mathrm{C} に$ 加熱された 溶融ピッチに浸漬し，ピッチ含浸した後，1000․ㅡㄴ に加熱処理を行なったものも測定用試料として用いた。

\section{2 放電特性試験方法}

上記した方法により得た同一製作条件の試料を 0.08 $\mathrm{mm}$ のスペーサーをはさんで相対するように電極支持器 に組込んで下記に示す 2 通りの放電試験を行なった。

\subsection{1 繰返し放電試験}

繰返し放電試験に用いた回路は第 1 報 $^{1)}$ に報告したも

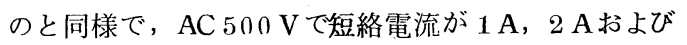
$3 \mathrm{~A}$ と変えられるように回路を調整した。まず最初の放 電開始電任を求め, 放電時間 $1 \mathrm{sec}$, 休止時間 $30 \mathrm{sec} の$ サイクルで繰返し放電を行ない, 最初の放電と繰返し放 電後の放電開始電纴の変動を求めて, 極の安定性の尺度 とし，また綝返し放電回数に対する電極間の短絡回数を 求めて極の耐久性の尺度とした。

\section{2 .2 衝撃放電試験}

衝撃放電試験に用いた回路はFig. 1 に示す通りで, 先 ずュンデンサーに充電し，次いで回路を閉じて電極間に 放電を行なわせた。衝撃放電電流は第 1 報 $に$ に述べたもの と同様である。一回の放電が終了するたびに電極間に $48 \mathrm{~V}$ の電位差を与え, 短絡の有無をしらべた。このよ うにして試料電極が短絡するまで衝撃放電をくり返し, 短絡をしない放電回数を求め, 極の安定性および酎久性 の尺度とした。

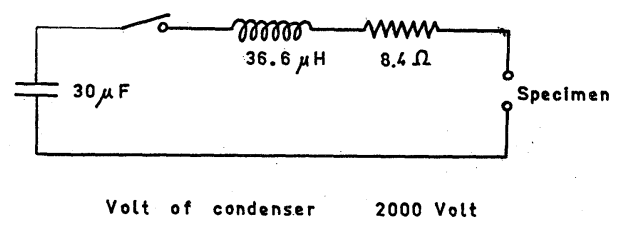

Fig. 1 Electric circuit of pulsed discharge

\section{3. 実験結果}

\section{1 繰返し放電試験}

A-NGP 20 試料の加熱処理温度 (HTT) による最初 の放電開始電压, 繰返し放電を行なった後の放電開始電 圧の変化をTable 2 に示す。また最初の放電開始電比 と第 20 回目または第 100 回目の放電開始電代との差 $\Delta V$ と最初の放電開始電生 $V$ との比 $\Delta V \mid V$ の值と HTT との関係を Fig. 2 に示す。

$\Delta V \mid V$ の值は何れの場合も HTT の増加とともに減少 し, HTT約 $1400^{\circ} \mathrm{C}$ で極小を示し, 以後HTT とともに 増加し, HTT約 $2000^{\circ} \mathrm{C}$ で極大を示し, その後HTT の 
Table 2 The threshold voltage in the reptitive discharge for A-NGP $20^{*}$

\begin{tabular}{|c|c|c|c|}
\hline HTT & $\begin{array}{l}\text { Threshold } \\
\text { voltage at } \\
\text { the 1st dis- } \\
\text { charge }\end{array}$ & $\begin{array}{l}\text { Threshold } \\
\text { voltage at } \\
\text { the 20 th } \\
\text { discharge }\end{array}$ & $\begin{array}{l}\text { Threshold } \\
\text { voltage at } \\
\text { the 100 th } \\
\text { discharge }\end{array}$ \\
\hline${ }^{\circ} \mathrm{C}$ & volt & volt & volt \\
\hline 1000 & 443 & 352 & 342 \\
1200 & 440 & 391 & 388 \\
1400 & 453 & 413 & 401 \\
1600 & 436 & 364 & 312 \\
1800 & 446 & 320 & 273 \\
2000 & 415 & 290 & 260 \\
2200 & 420 & 289 & 271 \\
2400 & 424 & 315 & 320 \\
2600 & 419 & 361 & 374 \\
2800 & 429 & 390 & 447 \\
\hline
\end{tabular}

* Average values of five experimental lots

$$
\begin{aligned}
& \text { at } 20 \text { th discharge } \\
& \text { at } 100 \text { th discharge }
\end{aligned}
$$

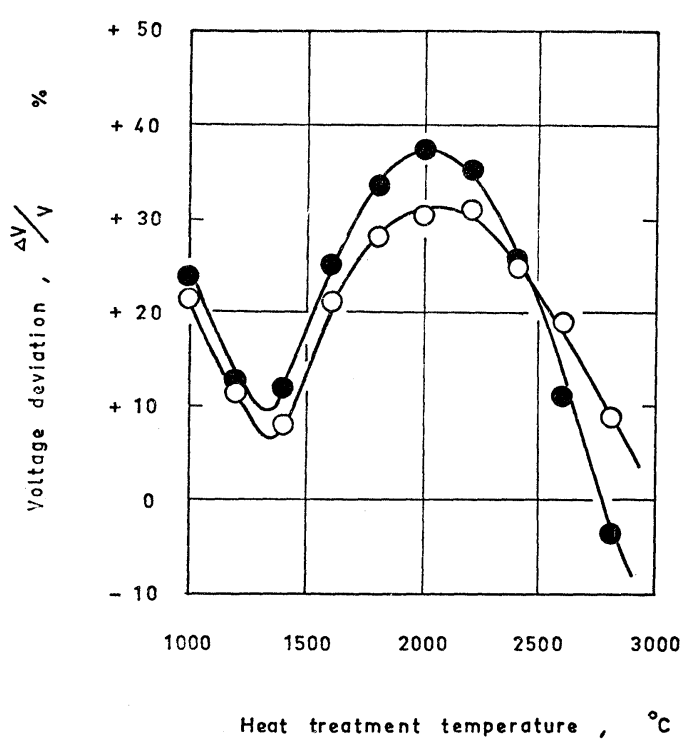

Fig. 2 Relation between the voltage deviation of repetitive discharge and the heat treatment temperature for A-NGP 20

増加とともに再び減少する。これは，HTT $1400^{\circ} \mathrm{C}$ 付 近㧍よびHTT $2800^{\circ} \mathrm{C}$ 付近で放電が極めて安定である ことを示している。

Table 3 にNGP の割合を変えた場合および放電電 流值を変えた場合の繰返し放電回数中における電極間の
短絡回数を示す。

Table 3 The number of occurence of shortcircuiting for the repetitive discharge

\begin{tabular}{|c|c|c|c|}
\hline $\begin{array}{c}\text { Content } \\
\text { of NGP }\end{array}$ & $\begin{array}{c}\text { HTT } \\
{ }^{\circ} \mathrm{C}\end{array}$ & $\begin{array}{l}\text { per 500 dis- } \\
\text { charges at 2A } \\
\text { discharge } \\
\text { current }\end{array}$ & $\begin{array}{l}\text { per 240 dis - } \\
\text { charges at 3A } \\
\text { discharge } \\
\text { current }\end{array}$ \\
\hline A-NGP20 & 2000 & 17 & 160 \\
2000 & 3 & 53 \\
\hline A-NGP40 & 1200 & 2 & 171 \\
& 2000 & 1 & 32 \\
\hline NGP 100 & 20000 & 0 & 7 \\
\hline
\end{tabular}

* impregnated with pitch

NGP の割合を増すとともに繰返し放電の短絡回数は 少なくなり，放電電流を大にするとともに短絡回路は大 となることがわかる。また，ピッチ含浸したものの方が ピッチ含浸をしないものに比して短絡回数は減少する。

\section{2 衝撃放電試験}

Table 4 にHTTを変えた場合およびNGP の割合を 変えた場合の短絡を起こさない㣫撃放電回数を示す。

A-NGP 20 試料では明らかにHTT の増加とともに 短絡を起こさない衝撃放電回数は増加することがわかる が, A-NGP 80 試料では HTT $2000^{\circ} \mathrm{C}$ 付近で極大を示 寸傾向がある。

また, NGP の割合の減少とともに短絡を起こさない 重撃放電回数は増加し, 衝撃放電に対する安定性が良く なることがわかる。

Table 5 にHTT $2800^{\circ} \mathrm{C}$ で処理した試料につき NG $\mathrm{P}$ の割合を変化した場合の短絡を起こさない衝撃放電回

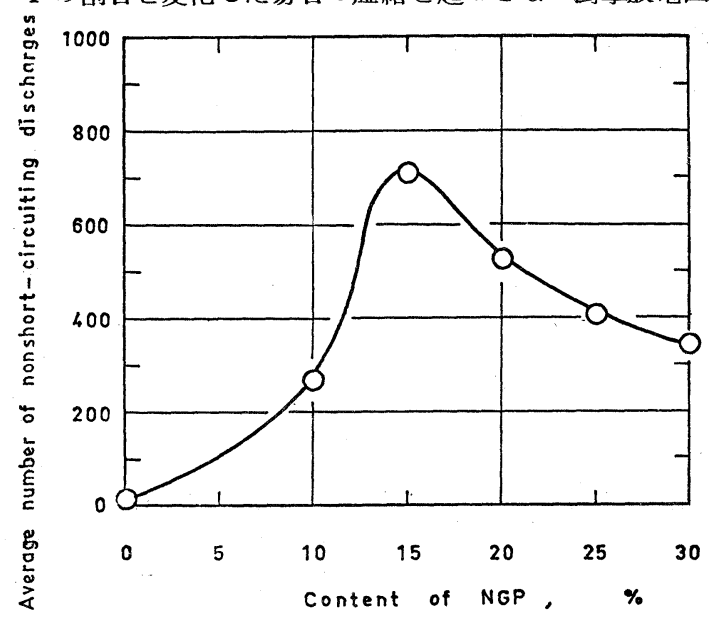

Fig. 3 Relation between the average num ber of nonshort-circuiting discharges in the pulsed discharge and the content of NGP for A-NGP ( HTT $2800^{\circ} \mathrm{C}$ ) 
Table 4 The number of nonshort-circuiting discharges for the pulsed discharge

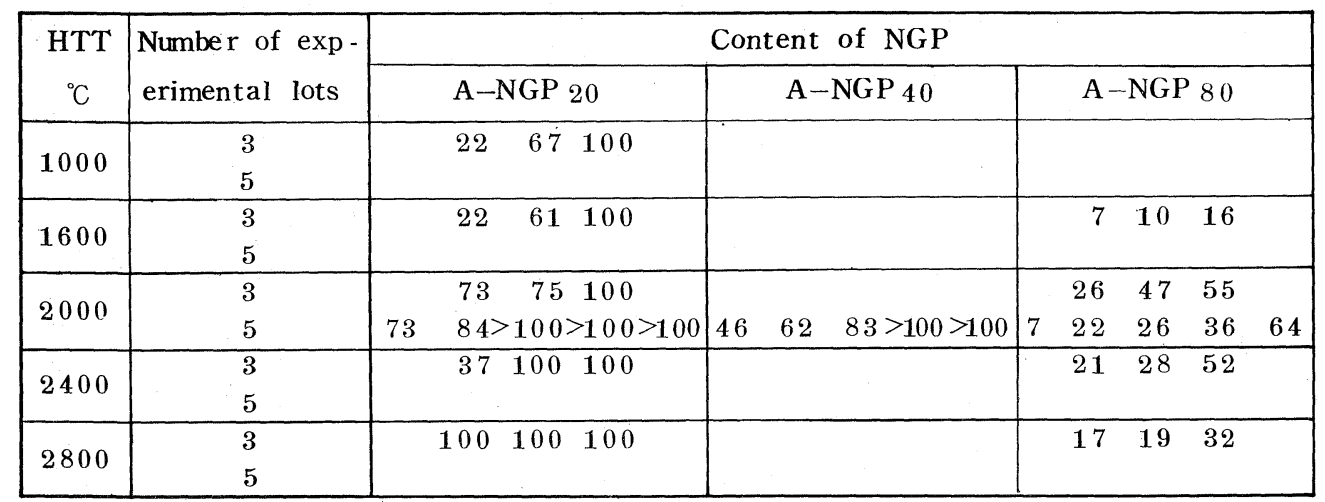

Table 5 The number of nonshort-circuiting discharges in the pulsed discharge for A-NGP (HTT $2800^{\circ} \mathrm{C}$ ) and commercial arrester carbons

\begin{tabular}{|c|c|c|c|}
\hline Samples & $\begin{array}{c}\text { Number of exp- } \\
\text { erimental lots }\end{array}$ & $\begin{array}{c}\text { Number of nonshort }- \\
\text { circuiting discharges }\end{array}$ & Ave rage value \\
\hline A-NGP 10 & 5 & $82-714$ & 272 \\
A-NGP 15 & 10 & $191-1997$ & 714 \\
A-NGP 20 & 10 & $104-1100$ & 528 \\
A-NGP 25 & 10 & $144-826$ & 411 \\
A-NGP 30 & 10 & $90-1240$ & 345 \\
\hline a (made in Japan) & 10 & $38-842$ & 59 \\
b (made in Japan) & 10 & $1-79$ & 17 \\
c (made in U.S.A.) & 10 & & 95 \\
\hline
\end{tabular}

数を示す。Table 5 には 2 種の日本製 $(a, b)$ および 1 種の米国製 (c)の現用避雷器用炭素の值も示した。A -NGP試料で短絡を起こさず衝撃放電が約 2000 回近 くも繰り返えせるものがあることは非常に注目すべきこ とである。

Fig. 3 にHTT $2800^{\circ} \mathrm{C}$ で処理した試料につき，短絡 を起こさない衝撃放電回数の平均值と NGP の割合との 関係を示す。

NGPの割合が約 $15 \%$ で極大を示し，短絡を起こさな い衝撃放電回数が約 700 回にも達することが明らかであ る。

\section{4. 考察}

赤平炭単味 $\mathrm{A}$ の場合は, 繰返し放電ではHTT $1400^{\circ} \mathrm{C}$ 付近が最も安定で, 次いでHTT $2000^{\circ} \mathrm{C}$ 付近が安定, HTT $2800^{\circ} \mathrm{C}$ 付近が最も不安定となり, 連続放電, 衝撃 放電ではHTT $2000^{\circ} \mathrm{C}$ 付近が最も安定で, 総じてHTT $2000^{\circ} \mathrm{C}$ 付近が気中放電に対し最も安定であることは第 2 報 $^{2)}$ に述べた。
これに対し，A-NGP 20 の場合は，繰返し放電では HTT $1400^{\circ} \mathrm{C}$ 付近および HTT $2800^{\circ} \mathrm{C}$ 付近が安定で, HTT $2000^{\circ} \mathrm{C}$ 付近が最も不安定であり, 衝撃放電では, HTT $2800^{\circ} \mathrm{C}$ が安定で，HTTの低下とともに安定度が 悪くなる。従って, この場合は, 総じて HTT $2800^{\circ} \mathrm{C}$ 付近が気中放電に対し最も安定であることがわかる。

繰返し放電に対する極の耐久性を放電電流 $3 \mathrm{~A}$, 放電 回数 240 回の繰返し放電中に短絡を起こした回数百分率 で表わし，衝撃放電に対する極の耐久性を短絡を起こさ ない衝撃放電回数とすると，A-NGP (HTT $2000^{\circ} \mathrm{C}$ ) の放電に対する耐久性と NGP の含有割合との関係は Fig. 4 の如くなる。すなわち, 繰返し放電に対しては NGPの含有割合の多いものほど耐久性が大となり，重 撃放電に対しては NGP の含有割合の少ないものほど耐 久性が大となる。但し，NGP を含まない赤平炭単味 A の場合には衝撃放電に対する耐久性が再び小さくなるこ とは，第 2 報 $^{2}$ およびFig. 3 から明らかである。このよ うに NGP の増加は, 繰返し放電に対しては正の効果を 示しているが，衝撃放電に対しては負の効果を示し，且 


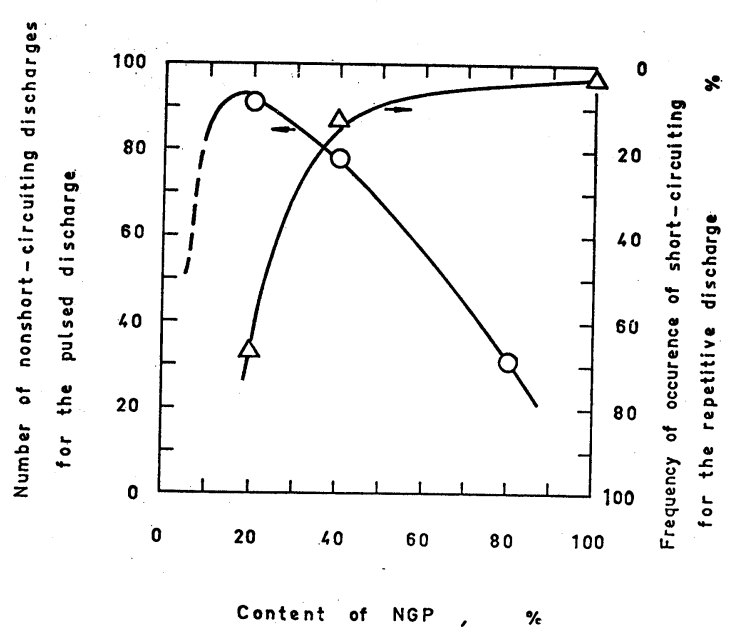

Fig. 4 Relation between durability of A-NGP $\left(\right.$ HTT $2000^{\circ} \mathrm{C}$ ) for the discharges and content of NGP

つ，機械的強度の低下をもたらすことが明らかであるの で, 実用面では問題にならないと思われる。

従って，放電に対する安定性および耐久性を考えれば， A-NGP $10 \sim \mathrm{A}-\mathrm{NGP} 30$ (HTT $\left.2800^{\circ} \mathrm{C}\right)$ が避雷器用 炭素として適当であろうと考えられる。

Table 6 にAおよびA-NGP2 0 の見掛比重, ショ アー硬度および電気比抵抗の值を示す。A-NGP 20

Table 6 Apparent density, Shore hardness and electrical specific resistance of $A$ and A-NGP 20 heat trected at $1000^{\circ} \mathrm{C}$ and at $2000^{\circ} \mathrm{C}$

\begin{tabular}{|c|c|c|c|c|}
\hline $\begin{array}{l}\text { HTT } \\
{ }^{\circ} \mathrm{C}\end{array}$ & Sample & A. D. & Hs & $\rho \mathrm{m} \Omega-\mathrm{cm}$ \\
\hline 1000 & $\begin{array}{c}A \\
A-N G P=0\end{array}$ & $\begin{array}{c}1.42 \\
1.32 \sim 1.55\end{array}$ & $\begin{array}{c}75 \\
55 \sim 80\end{array}$ & $\begin{array}{c}17.21 \\
=14.8 \sim 50.2 \\
+\quad 32 \sim 19.2\end{array}$ \\
\hline 2000 & $\begin{array}{c}\mathrm{A} \\
\mathrm{A}-\mathrm{NGP} \mathbf{2}_{2}\end{array}$ & $\begin{array}{c}1.31 \\
1.42 \sim 1.50\end{array}$ & $\begin{array}{l}76 \sim 78 \\
61 \sim 75\end{array}$ & $\begin{array}{c}7.67 \\
=5.67 \sim 6.75 \\
\perp \quad 0.22 \sim 0.60\end{array}$ \\
\hline
\end{tabular}

" parallel to pressure direction

$\perp$ tangential to pressure direction

(HTT $\left.2000^{\circ} \mathrm{C}\right)$ は A (HTT $\left.2000^{\circ} \mathrm{C}\right)$ に比較して見掛比 重, ショア一硬度はたいして変化していないが, 電気比抵 抗の值, 特に成形圧力に垂直方向の值が数十分の一に低 下している。このことが赤平炭を基材とし，これに天然
黒鉛を適当量添加し，かつ適切な温度に加䓡処理したま のが，繰返し放電，衝撃放電，いずれに対しても従来の 市販避雷器用炭素にみられないような極めて優秀な性質 を示す大きな原因となっていると思われる。

\section{5. 総括}

（1）赤平炭を基材とし，精製天然黒鉛とピッチの混合 物を添加材として, 添加量, 熱処理温度を変えて避雷器 用電極としての炭素材料を試作した。

（2）得られた炭素材料について, 放電試験として繰返 し放電, 衝擊放電による放電特性（安定性, 耐久性）を 測定した。

（3）繰返し放電に対しては熱処理温度 $1400^{\circ} \mathrm{C}$ ならび に $2800^{\circ} \mathrm{C}$ 付近の素材が最も安定であった。衝撃放電に 対しては熱処理温度 $2800^{\circ} \mathrm{C}$ 付近の素材が最も安定であ つた。

（4）繰返し放電に対しては添加材の量の多いものほど 耐久性が大であった。これに反し, 衝撃放電に対しては 添加材の量の多いものほど耐久性が悪くなり, 添加量 $15 \%$ 程度のものが最も良好な結果を示した。

（5）赤平炭を基材とし, 天然黒鉛とピッチとの混合物 を添加材として $10 \sim 30 \%$ 程度添加し, $2800^{\circ} \mathrm{C}$ で熱処理 したものの衝撃放電特性は現用品（国内品および米国品） のいずれよりも，はるかに秀れていることが明らかとな った。

\section{文献}

1）本田英昌, 真田雄三, 原崎三郎, 菅井恭輔 : 炭素, 47, 23(1966)

2) H. Honda, Y. Sanada, T. Furuta : Carbon，投稿 中 本田英昌, 真田雄三, 古田毅 : 炭素, 48,2(1967)

3）本田英昌：“放電加工技術便覧”，日刊工業新聞社， p. $142(1963)$

4) H. Honda, 1st International Conference on EDM, Text No. 1, 13 (1965)

5）本田英昌, 持田直之, 真田雄三：資源試報告, No. 44, (1958)

6) H. Honda, K. Egi, S. Toyoda, Y. Sanada : C arbon, 1, 155 (1964)

7) H. Honda, Y. Sanada and T. Furuta : Carbon, $3,421(1966)$

(42. 3.13) 